\section{Legislation Committee Update}

\section{John Shuler}

A $s$ the new Chair, it is my hope that GODORT's Legislation Committee can, in a structured and deliberative fashion, help our membership become more engaged advocates for the broad access to civic/government information resources and services. The Legislation Committee can help librarians - whether GODORT members or not-recognize how the seemingly multifaceted initiatives other private and public interest groups attempt to shape government information policy—and why our members now to become more directly involved in these conversations and efforts.

Our Association's traditional and future advocacy goals seek to sustain a robust set of laws, regulations, policies and/or judicial decisions necessary for the democratic and transparent availability of government information.

I also think GODORT's legislative advocacy needs to embrace a more comprehensive program of education, advocacy and study about what happens at the state, regional, local, and international levels of government. It seems, to me at least, that the past quarter century of partisan politics demands a new kind of librarian advocacy. The way the national, state and local governments now must interact with each other, especially with the widespread of use of e-government tools and services, I think expects a different kind of government information librarian perspective.

The ways we can inform Association members, and the profound challenges to our democratic ideals of open government information, happens in a much more dynamic and interdependent fashion among all levels of government and though all kinds of libraries-whether formal depositories or not.

I think the Legislative Committee can lend a great deal to helping GODORT members understand what it means to be a practicing librarian who can take a leadership role in their library and/or organization to make the best choices for the collection, organization, public service and curation of all kinds of government information resources. It can be a form of advocacy and civic engagement that recognizes the limitations or resources of the local institution, but also help that institution understand that every "public" library in our democratic community enjoys the responsibility, availability and obligation to think about their civic purposes to reasonably engage their communities (and collections or services) in the robust support of an open, engaged and accessible system of government information resources and services.

Part of this will draw upon our traditional formats of paper and print (and a level of advocacy to demand their proper preservation and curation going forward deeper into our digital age). Nearly two hundred years of librarian expertise, knowledge and practice fashioned from depository library our collective depository practice is one of our profession's essential tools that bind the technologies of democracy with the civic purposes government information. This is experience that ALA and its members need now as much more than ever.

So, as incoming Chair of Legislation, here are three basic goals I would like to see coming out of the annual San Francisco conference and working towards our two conferences in 2016, as well as help GODORT build on its existing excellent expertise in government information advocacy now and over the next five years.

1. Build on our existing methods/tools/organizations of advocacy that inform GODORT members about critical issues that directly affect the accessibility and curation of government information resources/services that speak to all levels of government. This supports our long-standing cooperative working with other ALA mechanisms of advocacy that speak to tactical and immediate threats or opportunities to government information at the national level (e.g. ALA's Washington Office, GIS and Legislation Committees.) But this also suggests that the Legislation Committee can/may take a stronger role in working with other GODORT committees to make necessary links and connections within their work/agendas that include critical and interdependent legislative, legal and policy issues.

2. Find common cause, purpose and ways to work with other Library Associations, the GPO Depository Library Council community, as well as state and regional library associations. Success in this kind of broad-based cooperation means these other national associations and groups could readily find and include the thinking, experience, expertise and advocacy of GODORT members in these larger advocacy conversations about a robust system of government information access, service and curation.

3. Develop ways of communicating and creating opportunities of engagement/discussion to engage GODORT members (and other interested library workers) beyond the Midwinter and Summer national conferences and their venues of meetings. This may include digital communications, digital 
conferences, or calls for participation at other regional/ national library group meetings.

I look forward to working with GODORT members over the coming year, and beyond, as we build on our earlier successes and challenges.
John Shuler (johnalfredshuler@gmail.com) is an Associate Professor, and Bibliographer/Liaison for College of Urban Planning and Public Administration, the Jane Addams College of Social Work, as well as the Government Information Librarian at the University of Illinois at Chicago's University Library. 